\title{
Clinicopathological evaluation of non-parasitic dermatoses in canines
}

\author{
M. J. Sindha ${ }^{1}$, B. J. Trangadia ${ }^{2}$, P. D. Vihol ${ }^{2}$, R. S. Parmar ${ }^{3}$ and B. V. Patel ${ }^{4}$
}

1. Animal Disease Diagnostic Laboratory, Amul Dairy, Mogar, Gujarat, India; 2. Department of Veterinary Pathology, College of Veterinary Science \& Animal Husbandry, Navsari Agricultural University, Navasari, Gujarat, India; 3. Poultry Complex, College of Veterinary Science \& Animal Husbandry, Anand Agricultural University, Anand, Gujarat, India; 4. Cambay Satellite Dairy, Amul Dairy, Undel, Gujarat, India.

Corresponding author: M. J. Sindha, e-mail: drmehulpathologist@gmail.com, BJT: drbjt77@gmail.com, PDV: drpritivet@gmail.com, RSP: drrohit.vet23@rediffmail.com, BVP: bhavesh4yuva@gmail.com

Received: 15-07-2015, Revised: 11-10-2015, Accepted: 19-10-2015, Published online: 24-11-2015

doi: 10.14202/vetworld.2015.1346-1350 How to cite this article: Sindha MJ, Trangadia BJ, Vihol PD, Parmar RS, Patel BV (2015) Clinicopathological evaluation of non-parasitic dermatoses in canines, Veterinary World 8(11): 1346-1350.

\begin{abstract}
Aim: The present study has been carried out to detect non-parasitic dermatoses in canines brought at the Nandini Veterinary Hospital, Surat.

Materials and Methods: The current investigation was carried out on skin scrapping, skin biopsy specimens, blood, and serum samples of 210 freshly registered cases of dogs with dermatological afflictions. Dogs found healthy on clinical examination were used as control animals $(n=15)$. The incidence of non-parasitic dermatoses has been recorded as per age, breed, and sex of dogs. For bacterial isolation, the pus/exudates samples were collected from 40 cases of pyoderma and streaked onto brain-heart infusion agar while 13 skin scrapping samples were inoculated on Sabouraud's dextrose agar with chloramphenicol for isolation of fungi. The organisms were identified on the basis of gross and microscopic observation of cultural growth on media. The blood and sera samples were also collected to note alteration in hematology and biochemical parameters, respectively. Tissue samples from lesions were collected and subsequently preserved in $10 \%$ neutral buffered formalin for histopathology.
\end{abstract}

Results: Out of 210 cases of dermatoses, 60 cases were of non-parasitic dermatoses, i.e., 28.57\%. Of these, bacterial skin infections (pyoderma) were found to be the predominant at $80.00 \%$, followed by other non-parasitic dermatological disorders, i.e., $11.67 \%$ and fungal skin infection, i.e., $8.33 \%$. The dogs belonging to age group 1-3 years showed greater susceptibility to non-parasitic dermatological conditions. Breed wise incidence of pyoderma was found more in the Pomeranian breed (20.83\%), whereas fungal skin affections were found to be higher in mongrel breed $(60.00 \%$ and $42.86 \%$, respectively). Male dogs showed greater involvement in bacterial, fungal, and other non-parasitic dermatoses. Bacteriological culture examination of 40 pus swabs resulted in the growth of 39 bacterial isolates. Mycological culture of skin scrapings from 13 suspected cases of fungal dermatoses resulted in the recovery of five fungal isolates.Hematological and serum biochemical parameters revealed a significant difference in all cases of non-parasitic dermatoses.Histopathological study revealed characteristic changes like infiltration of neutrophils with perifolliculitis, hyperkeratosis, and rafts of acantholytic cells. Histochemical staining revealed purple or magenta color fungal elements.

Conclusion: Based on current experiment it has been concluded that among non-parasitic dermatoses bacterial and fungal skin infections are the main ailments, followed by nutritional and other causes in adult and male dogs which can be diagnosed by cultural inoculation, microscopic examination of skin scrapings, and dermatohistopathology along with hematology and biochemistry.

Keywords: bacterial, canines, fungal, non-parasitic dermatoses.

\section{Introduction}

Dogs are members of the order Carnivora, a group of mammals with origin in the tertiary era, about 55 million years ago [1].The strong bonding between dog owners and pet dogs leads to concern about health and well-being of their pets and, therefore, the affected dogs are often brought to veterinary clinics for early diagnosis and treatment. Skin is the largest organ and outermost integument of the body and, therefore, is exposed to the adversities of the environment, allergens, pathogenic organisms and various toxic substances. "Dermatitis" is described as an inflammatory condition of skin regardless of the cause.

Copyright: The authors. This article is an open access article licensed under the terms of the Creative Commons Attributin License (http:// creative commons.org/licenses/by/2.0) which permits unrestricted use, distribution and reproduction in any medium, provided the work is properly cited.
In small animal clinics, dermatological disorders constitute a majority of cases and are estimated to range between $12 \%$ and $75 \%$ as the chief or concurrent owner complaint $[2,3]$. Almost every dermatological disease of the dog can have bacterial pyoderma as a component [4]. There are so many agents that cause dermatitis including bacteria, fungi, yeasts and also other factors such as age, season and inadequate or unbalanced nutrition. The diagnosis can be made on the basis of history, physical examination, hematobiochemical findings, skin scrapping examination, cultural isolation of pathogens using various selective, and enrichment media from clinical specimens. Skin biopsies can be collected for histopathological and histochemical examination.

The present study was planned with objectives, to study the pattern and distribution of the skin lesions, 
laboratory analysis of blood and biochemical parameters, examination of skin scrapings to elucidate the effects of non-parasitic dermatoses and pathomorphological and histochemical evaluation of skin sections to assess changes in skin biopsies in selected cases.

\section{Materials and Methods}

The current investigation was carried out on skin scrapping, skin biopsy specimens, blood and serum samples of 210 freshly registered cases of dogs with dermatological affections. Out of 210 cases of dermatoses, 60 cases were of non-parasitic dermatoses, i.e., $28.57 \%$. Of these, bacterial skin infections (pyoderma) were found to be the predominant at $80.00 \%$, followed by other non-parasitic dermatological disorders, i.e., $11.67 \%$ and fungal skin infection, i.e., $8.33 \%$. Those animals found healthy on clinical examination were used as a control, and the hematobiochemical values of dogs with non-parasitic dermatosis were compared with them $(n=15)$.

\section{Ethical approval}

The present experiment has been carried out on apparently ail animals and include no any clinical trials on animals, further the author have taken informed consent of the pet owners.

\section{Study area}

The present investigation was carried out on dogs brought at the Nandini Veterinary Hospital, Surat. Hemato-biochemical analyses were carried out in the Pathology Laboratory of Nandini Hospital, Surat. Histopathological and histochemical staining work was carried out in the Department of Pathology, College of Veterinary Science and Animal Husbandry, while the estimation of zinc was carried out in the Department of Agricultural Chemistry and Soil Science, NAU, Navsari.

\section{Collection of materials}

Skin scrapping was collected from superficial and deep lesions as per established method $[5,6]$ following strict aseptic measure in a test tube containing $10 \%$ of $\mathrm{KOH}$ and processed it for microscopic examination. Blood samples for evaluation of hematological parameters viz.hemoglobin $(\mathrm{Hb})(\mathrm{g} \%)$, packed cell volume (PCV) (\%), total leukocyte count (TLC) $\left(10^{3} / \mathrm{cumm}\right)$, total erythrocyte count (TEC) $\left(10^{6} / \mathrm{cumm}\right)$, and differential leukocyte count (\%), were collected from jugular vein in a glass vials containing ethylenediaminetetraacetic acid and sera samples for biochemical parameters such as total protein $(\mathrm{g} / \mathrm{dl})$, albumin $(\mathrm{g} / \mathrm{dl})$, globulin $(\mathrm{g} / \mathrm{dl}), \mathrm{A} / \mathrm{G}$ ratio, cholesterol $(\mathrm{mg} / \mathrm{dl})$, and zinc $(\mu \mathrm{mol} / \mathrm{L})$ were separated after clotting of blood by means of centrifugation at $500 \mathrm{G}$ for $10 \mathrm{~min}$ with $0.1 \%$ methiolate asa preservative. The sample for bacteriological culture were collected as per sampling technique described by previous researchers [7] and inoculated on brain-heart infusion agar for primary isolation of bacteria, and Gram's staining was performed for morphological characteristics of organism.
For mycological culture and isolation, skin scales and epilated hairs were cultured on the slant containing Sabouraund's dextrose agar with chloramphenicol at $37^{\circ} \mathrm{C}$ and examined at every 4-6 days up to 3-4 weeks for fungal growth. The gross appearance was on the basis of colonial growth on the test tube. For microscopic morphological examination, the slides containing isolates were stained with lectophenol cotton blue/ Narayan stain and the presence of hyphae, spores were recorded as per the suitable method [8].Collection of skin biopsy specimens were performed after locally anesthetizing the site ( $2 \%$ lidocain + epinephrine) using $3 \mathrm{~mm}$ circular punch at a depth of $2 \mathrm{~mm}$ in $10 \%$ neutral buffer formalin and subsequently stained with $\mathrm{H}$ and $\mathrm{E}$ stain [9].

\section{Statistical analysis}

The data generated on hematological, biochemical, and trace mineral observations were subjected to statistical analysis for test of significance by applying appropriate statistical methods [10].

\section{Results and Discussions}

In present study, after screening of 210 dogs with dermal affection 60 cases were found of non-parasitic dermatoses, out of theses 60 cases bacteria was found as an etiological agent in 48 cases $(80 \%)$ and fungal infection was reported in 5 cases $(8.33 \%)$. The highest incidence of both this condition was observed in the dogs of 1-3 years age group. Similar observation was made by other investigators [11-13] while some researcher reported the highest incidence of bacterial dermatitis in the dogs below 1 year of age (41.66\%) [14].When we considered breed, bacterial dermatoses (10 out of 48 cases) was the highest in Pomeranian whereas mycological affection (3 out of 5 cases) was maximum in mongrel dogs. High incidence of bacterial skin affection in long haired breeds of dogs was also reported by other researchers $[12,15]$. In current investigation, involvement of male dogs in bacterial and fungal dermatoses was observed to be more which was in agreement with a previous observation [15-17]. On bacteriological culture

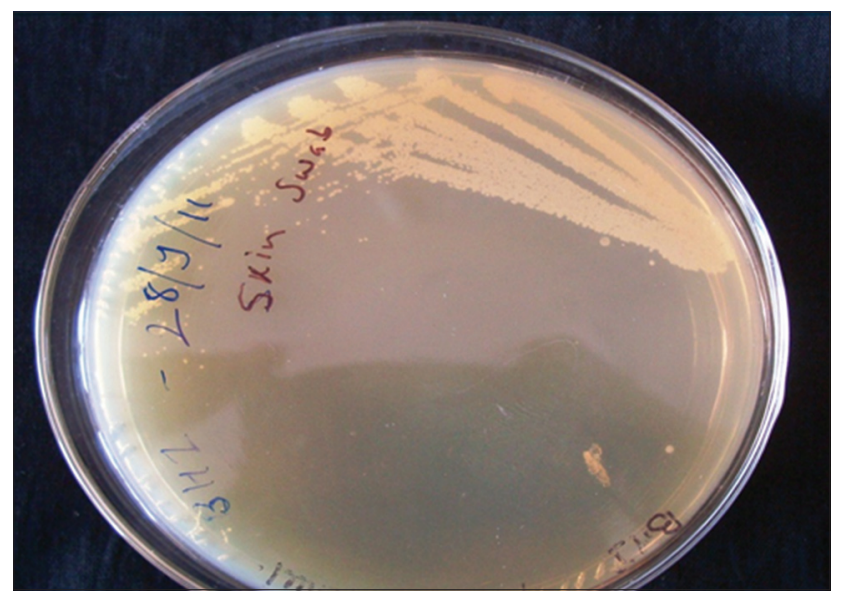

Figure-1: Dew drop like colonies of staphylococcus on BHI agar. 
inoculation of 40 pus swabs resulted in the recovery of 39 bacterial isolates, out of which 36 isolates were of Staphylococci spp.appearing as a dew drop like colonies $(92.30 \%)$ (Figure-1). Many workers have emphasized the role of Staphylococcusbacteria in producing pyogenic skin infections due to various exotoxins released by this organism $[16,18]$. Some investigators classified Staphylococci induced pyoderma into the surface $(13.6 \%)$, superficial $(66 \%)$ and deep pyoderma $(20.5 \%)$ [19]. The observation made by some researcher suggests that obesed dogs and dogs of the pug-nosed breed are frequently affected by bacterial pyoderma in skin folds on their face, lips and vulva [20]. The inherent resistance of Staphylococci limits the usefulness of some medication like tetracyclines and simple penicillins [21]. On inoculation of total 13 skin scrapping specimens suspected for fungal infection, only 5 (38.16\%) yielded isolates on mycological culture examination (Figure-2). Similar finding was obtained by earlier investigators[17] with only $10 \%$ positive cultures out of 8349 inoculated. Some researchers [22] reported that Microsporum canis and Trichophyton mentagrophytes infection in dogs was $4.4 \%$ and $2.2 \%$, respectively while other [23] isolated Penicillium spp. (19.80\%) and Aspergillus spp. (26.73\%). The Trichophyton spp. (23\%) was also frequently isolated along with Microsporum spp. (3\%) and Epidermophyton spp. (1\%) [24].The sample size of skin scrapings under this study was too small to draw conclusions about the result.

Hematological parameters in current study showed significant variation. The average values of $\mathrm{Hb}, \mathrm{PCV}$, and TEC were significantly lower in bacterial, fungal and other non-parasitic dermatological conditions when compared to control (Table-1). These findings were in agreement with previous results [25]. This decreased might be due to the reduced appetite and blood loss from scratching and inflammation while TLC values were found significantly higher in all cases of non-parasitic dermatoses as compared with control (Table-1). The leukocytosis could have resulted from toxins released due to tissue damage or necrosis produced by inflammation or from secondary bacterial infection. The values of neutrophils were found significantly higher in cases of bacterial skin diseases and significantly lower in cases of fungal skin diseases whereas blood lymphocytes showed visa-vis results when compared with control (Table-2). Neutrophilia in bacterial dermatitis might be due to mobilization of marginal and bone marrow granulocytic pool, and lymphocytosis as observed in fungal dermatitis could be due to persistent antigenic stimulation by chronic infection or inflammatory reaction produced by fungal infection [26]. The values of eosinophils were significantly higher in cases of fungal and other non-parasitic dermatological conditions with no significant difference in bacterial skin diseases when compared with control in contrast the values of monocytes were significantly lower in cases of bacterial skin diseases with the absence of basophils in peripheral blood (Table-2). The average values of serum biochemical parameters were compared with mean of corresponding normal (control group, $\mathrm{n}=15$ ) dogs. The parameters such as serum globulin, $\mathrm{A} / \mathrm{G}$ ratio in bacterial, fungal, and other non-parasitic dermatological conditions showed a significant difference when

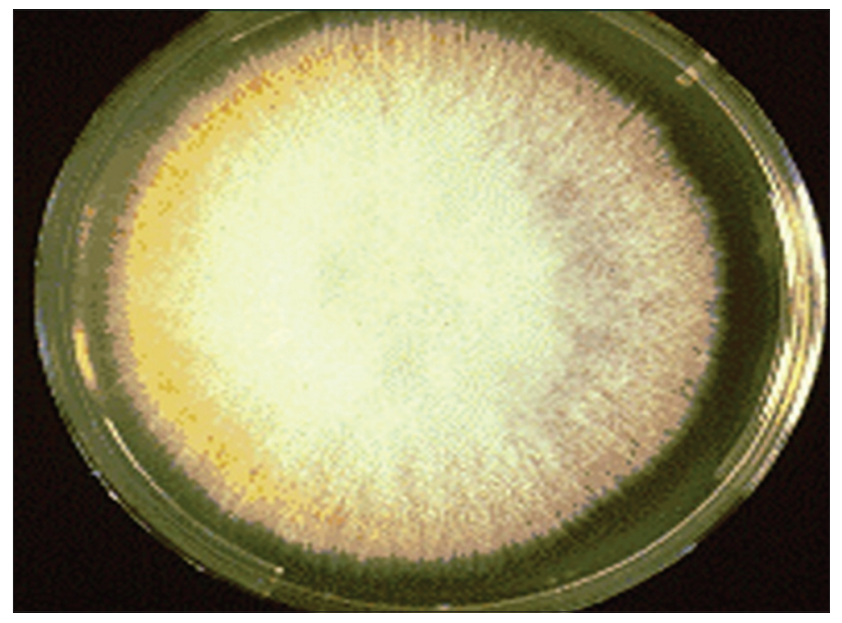

Figure-2: On Sabouraud's Dextrose Agar Microsporum canis produce white cottony to wooly appearing colony.

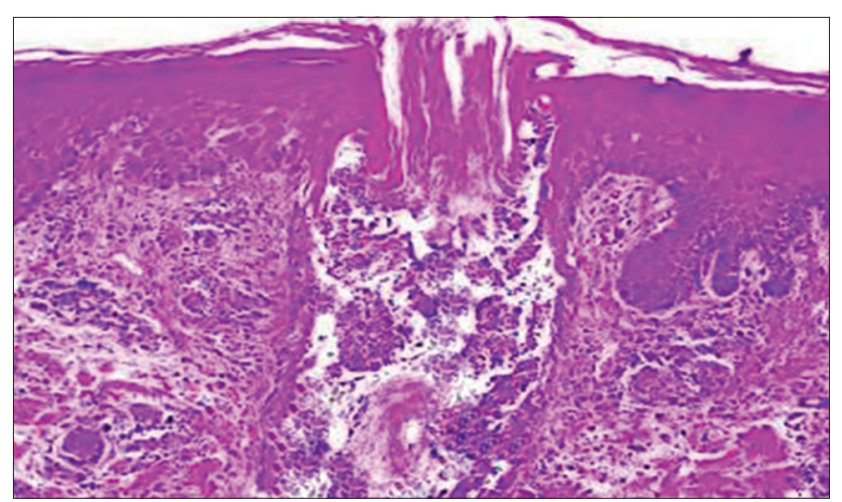

Figure-3: Perifolliculitis with infiltration of inflammatory cells $(H \& E, 100 X)$.

Table-1: Hematological profile (Hb, PCV, TEC and TLC) of dogs with non-parasitic dermatoses.

\begin{tabular}{|c|c|c|c|c|c|}
\hline \multirow[t]{2}{*}{ Groups } & \multicolumn{5}{|c|}{ Parameters (mean \pm SE) } \\
\hline & $\mathbf{N}$ & Hb $(g \%)$ & PCV (\%) & TEC $\left(10^{6} /\right.$ cumm $)$ & $\operatorname{TLC}\left(10^{3} /\right.$ cumm $)$ \\
\hline Control & 15 & $12.32 \pm 0.11$ & $36.23 \pm 0.11$ & $6.10 \pm 0.03$ & $9.29 \pm 0.07$ \\
\hline Bacterial skin infection & 28 & $09.80 \pm 0.34 * *$ & $29.40 \pm 1.03 * *$ & $4.90 \pm 0.17 * *$ & $14.21 \pm 0.18 * *$ \\
\hline Fungal skin infection & 05 & $09.97 \pm 0.36 * *$ & $29.92 \pm 1.08^{* *}$ & $4.99 \pm 0.18 * *$ & $14.70 \pm 0.20 * *$ \\
\hline Other non-parasitic dermatological conditions & 07 & $08.98 \pm 0.21 * *$ & $30.30 \pm 0.60 * *$ & $5.05 \pm 0.10 * *$ & $14.06 \pm 0.28 * *$ \\
\hline
\end{tabular}

**Highly significant at $\mathrm{p} \leq 0.01$, with reference to control, $\mathrm{N}=$ Number of observations, NS=Non significant,

$\mathrm{Hb}=$ Hemoglobin, PCV = Packed cell volume, TEC=Total erythrocyte count, TLC=Total leukocyte count, SE=Standard error 
Table-2: DLC profile for non-parasitic dermatoses in canines.

\begin{tabular}{|c|c|c|c|c|c|c|}
\hline \multirow[t]{2}{*}{ Groups } & \multirow[t]{2}{*}{$\mathbf{N}$} & \multicolumn{5}{|c|}{ DLC (\%) (mean \pm SE) } \\
\hline & & $\mathbf{N}$ & $\mathbf{L}$ & $\mathbf{E}$ & $\mathbf{M}$ & B \\
\hline Control & 15 & $67.33 \pm 0.23$ & $26.73 \pm 0.23$ & $2.27 \pm 0.25$ & $3.53 \pm 0.13$ & $0.20 \pm 0.11$ \\
\hline Bacterial skin infection & 28 & $76.59 \pm 0.61 *$ & $18.23 \pm 0.57 *$ & $2.64 \pm 0.14 *$ & $2.50 \pm 0.16 *$ & $0.00 \pm 0.00$ \\
\hline Fungal skin infection & 05 & $54.27 \pm 0.58 *$ & $37.00 \pm 1.61 *$ & $4.73 \pm 0.18 *$ & $3.73 \pm 0.23 *$ & $0.00 \pm 0.00$ \\
\hline Other non-parasitic dermatological conditions & 07 & $65.77 \pm 1.27 *$ & $27.61 \pm 1.26 *$ & $3.08 \pm 0.24 *$ & $3.54 \pm 0.18^{*}$ & $0.00 \pm 0.00$ \\
\hline
\end{tabular}

*Significant at $\mathrm{p} \leq 0.05$, with reference to control, $\mathrm{N}=$ Number of observations, NS=Non significant, DLC=Differential leukocyte count, $\mathrm{SE}=$ Standard error, $\mathrm{N}=$ Neutrophils, $\mathrm{L}=$ Lymphocytes, $\mathrm{M}=$ Monocytes, $\mathrm{E}=$ Eosinophils, $\mathrm{B}=\mathrm{Basophils}$

Table-3: Serum biochemical profile of non-parasitic dermatoses in canines.

\begin{tabular}{|c|c|c|c|c|c|}
\hline \multirow[t]{2}{*}{ Groups } & \multirow[t]{2}{*}{$\mathbf{N}$} & \multicolumn{4}{|c|}{ Parameters } \\
\hline & & $\begin{array}{l}\text { Total protein } \\
(\mathrm{g} / \mathrm{dl})\end{array}$ & $\begin{array}{l}\text { Albumin } \\
\text { (g/dl) }\end{array}$ & $\begin{array}{l}\text { Globulin } \\
\text { (g/dl) }\end{array}$ & A/G ratio \\
\hline Control & 15 & $7.36 \pm 0.10$ & $3.43 \pm 0.05$ & $3.93 \pm 0.13$ & $0.89 \pm 0.04$ \\
\hline Bacterial skin infection & 28 & $7.56 \pm 0.05$ & $3.31 \pm 0.03$ & $4.25 \pm 0.06 *$ & $0.78 \pm 0.02 *$ \\
\hline Fungal skin infection & 05 & $7.69 \pm 0.13$ & $3.33 \pm 0.10$ & $4.36 \pm 0.17 *$ & $0.77 \pm 0.05^{*}$ \\
\hline Other non-parasitic dermatological condition & 07 & $7.55 \pm 0.03$ & $3.32 \pm 0.04$ & $4.23 \pm 0.04 *$ & $0.78 \pm 0.01 *$ \\
\hline Total & 55 & & & & \\
\hline
\end{tabular}

Parameters

Zinc $(\mu \mathrm{mol} / \mathrm{L})$
Cholesterol $(\mathrm{mg} / \mathrm{dl})$

Mean \pm SE

\begin{tabular}{cc}
\multicolumn{2}{c}{ Mean \pm SE } \\
\hline Control & Treatment \\
$183.33 \pm 2.31(\mathrm{~N}=15)$ & $190.40 \pm 2.97(\mathrm{~N}=07)$ \\
$13.81 \pm 0.71(\mathrm{~N}=05)$ & $13.01 \pm 0.53(\mathrm{~N}=05)$
\end{tabular}

*Significant at $\mathrm{p} \leq 0.05$, with reference to control, $\mathrm{N}=$ Number of observations, NS=Non significant, $\mathrm{SE}=\mathrm{Standard}$ error, $\mathrm{A} / \mathrm{G}=$ Albumin globulin ratio

compared with normal control group, whereas other parameters were non-significant (Table-3). Significant increase in globulin with decreased $\mathrm{A} / \mathrm{G}$ ratio as observed in the current study was also observed by previous researchers [25].

The histopathological alterations observed in the biopsy specimens from pyoderma cases revealed mainly infiltration of neutrophils with perifolliculitis (Figure-3). Whereas biopsy from lesions of infected callus (pressure point pyoderma) revealed perifolliculitis, hyperkeratosis, and rafts of acantholytic cells. Sections of skin infected with fungi showed fungal spores and hyphae along with other pronounced histological changes such as hyperkeratosis, acanthosis, and follicular changes. Biopsy specimen from zinc responsive dermatoses revealed characteristic change of parakeratosis (Figure-4). Infiltration of these cells in cases of bacterial infections suggests immunological and inflammatory response of body defense mechanisms [11]. Mechanical disruption of the stratum corneum appears to be important in facilitating penetration of dermatophytes and might be responsible for inflammatory and histological changes in the skin. The skin sections from the cases of fungal skin infections were stained with the periodic acid-Schiff stain which revealed purple or magenta colored fungal hyphae (Figure-5) which concur with the findings of Kumar and Kiernan[27].

\section{Conclusion}

Based on current experiment it has been concluded that among non-parasitic dermatoses bacterial

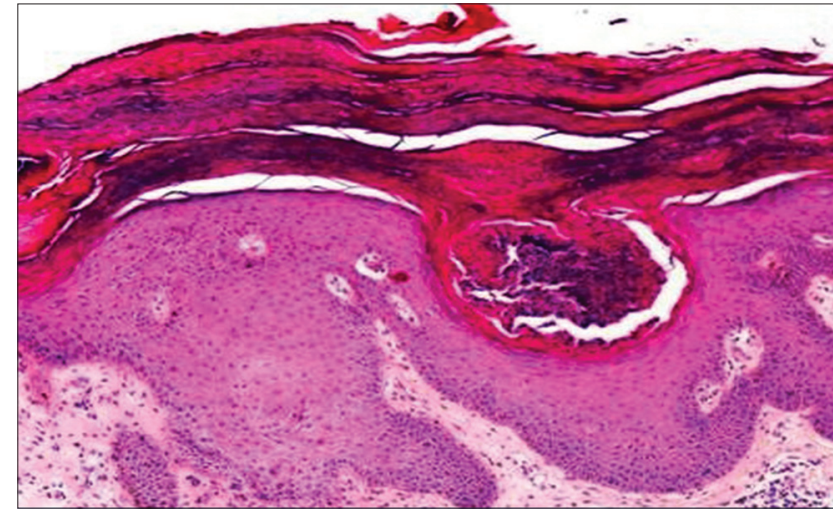

Figure-4: Skin biopsy sample from zinc responsive dermatoses revealed Parakeratosis ( $\mathrm{H} \& \mathrm{E}, 400 \mathrm{X})$.

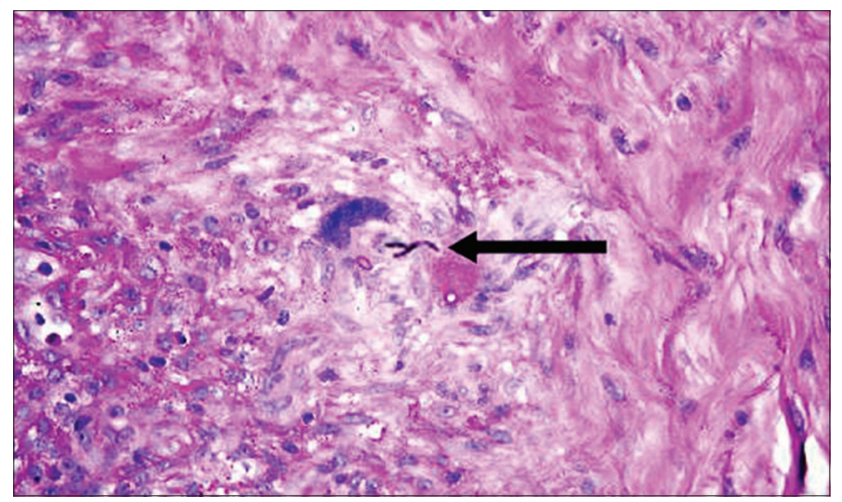

Figure-5: PAS staining of skin showing fungal hyphaearrow (400X).

and fungal skin infections are the main ailments, followed by nutritional and other causes in adult and 
male dogs which can be diagnosed by cultural inoculation, microscopic examination of skin scrapings, and dermatohistopathology along with hematology and biochemistry.

\section{Authors' Contributions}

MJS perform the study under the guidance of BJT and PDV. MJS and BVP perform the laboratory investigation of the samples. MJS and RSP drafted the final manuscript. The final manuscript was read and approved by all the authors.

\section{Acknowledgments}

Authors are highly thankful to the Nandini Hospital, Surat and College of Veterinary Science and Animal Husbandry, Navsari Agricultural University, Navsari for providing, encouraging and friendly atmosphere and technical assistance. Authors heartily thank late Dr.G.S.Rao.

\section{Competing Interests}

The authors declare that they have no competing interests.

\section{References}

1. Pachauri, S.P. (1999) Canine Preventive Medicine. Nilay Publication, Pantnagar. p111, 620-631.

2. Scott, D.W. and Paradis, M. (1990) A survey of canine and feline skin disorders seen in university practice: Small Animal Clinic, University of Montreal, Saint Hyacinthe, Quebec (1987-1988). Can. Vet. J.,31: 753-756.

3. Feijo, F.M.C., Souza, N.F. and de Ramadinha, R.H.R. (1998) A study of the yeast Malassezia pachydermatis by examination of skin cytology in the dog. Rev. Bras. Med. Vet.,20: 66-68

4. Srivastava, A.K. (2011) Staphylococcal pyoderma: An emerging crisis in canine practice. Indian.J. Canine Pract., 3(1): 7-12.

5. Al-Doory, Y. (1980) In: Al-Doory, Y., editor. Laboratory Medical Mycology. Lea and Febiger, Philadelphia. p249-283.

6. Scott, D.W., Miller, W.H. Jr. and Griffin, C.E. (1995) Muller and Kirk's Small Animal Dermatology. $5^{\text {th }}$ ed. Saunders, W. B, Philadelphia. p218-221, 244-258 and 279-328.

7. Nesbitt, G.H. (1983) Bacterial skin disease. In: Canine and Feline Dermatology: A Systematic Approach. Lea and Febiger, Philadelphia. p81.

8. Pal, M. and Singh, D.K. (1983) Studies on dermatomycoses in dairy animals. Mycoses, 26: 317-323.

9. Culling, C.F.A. (1969) Handbook of Histopathological and Histochemical Techniques. $3^{\text {rd }}$ ed. Butterworth and Company, Durban.

10. Snedecor, G.W. and Cochran, W.G. (1994) Statistical Methods. $8^{\text {th }}$ ed. USA, The Iowa State University Press.
11. Aujla, R.S., Singh, N., Sood, N., Gupta, P.P. and Sodhi, S. (1997) Bacterial dermatitis in dogs in Punjab Prevalenceand clinicopathological studies. Indian Vet. J.,74: 837-840.

12. Choi, W.P., Lee, S.I. and Lee, K.W. (2000) Aetiological and epidemiological features of canine dermatitis. Korean $J$. Vet. Res.,40: 94-100.

13. Shyama, V.H. and Vijaykumar, K. (2012) Epidemiological studies on bacterial skin infection in dogs. J. Vet. Anim. Sci., 43: 49-51

14. Singh, R., Bigh, S.A., Soodan, J.S., Tikoo, A. and Tantray, H. (2012) Clinico-epidemiological studies in canine dermatitis. Indian J. Canine Pract., 43: 49-51.

15. Patil, S.S., Madhava Rao, P. and Patil, N.A. (1999) Epidemiology and bacterial isolates in canine pyoderma. Indian J. Vet. Med.,19: 39-40.

16. Pal, A., Basak, D.N. and Chakrabarty, A. (1993) Epidemiological studies on canine pyoderma in West Bengal. Indian J. Anim. Health., 32: 121-125.

17. Sparkes, A.H., Gruffyd, J.T.J., Shaw, S.E., Wright, A.I. and Stokes, C.R. (1993) Epidemiological and diagnostic features of canine and feline dermatophytosis in the United Kingdom from 1956-1991. Vet. Rec.,133: 57-61.

18. Guilhon, J., Jolivet, G. and Marchand, A. (1974) Pyodermatitis in dogs (variation in bacterial flora). Bull. Acad. Vet. Fr.,47: 41-47.

19. Kelany, W.M. and Galal, H.M. (2011) Diagnosis of recurrent pyoderma in dogs by traditional and molecular based diagnostic assays and its therapeutic approach. J.Am. Sci., 7(3): 120-134.

20. Manjul, R.S. (2012) Common dermatological disease by bacteria and fungi in pet dogs.Indian J. Fundam. Appl. Sci., 2(2): 207-209.

21. Yoon, J.W., Lee, K.J., Lee, S.Y., Chae, M.J., Park, J.K., Yoo, J.H. and Park, H.M. (2010) Antibiotic resistance profiles of Staphylococcuspseudintermedius isolates from canine patients in Korea. J. Microbiol. Biotechnol., 20: 1764-1768.

22. T-Sai, Y.J., Chung, W.C., Wang, L.C., Ju, Y.T., Hong, C.L., T-Sai, Y.Y., Li, Y.H. and Wu, Y.L. (2011) The dog mite, Demodex canis: Prevalence, fungal co-infection, reactions to light, and hair follicle apoptosis. J. Insect. Sci., 11:76.

23. Nichita, I. and Marcu, A. (2010) The fungal microbiota isolated from cats and dogs. Anim.Sci. Biotechnol., 43(1): 411-414.

24. Senthil Kumar, K., Selvaraj, P., Vairamuthu, S., Nagarajan, B., Nambi, A.P. and Prathaban, S. (2011) Survey of fungal isolates from canine mycotic dermatitis in Chennai. Tamil Nadu J. Vet. Anim. Sci.,7(1): 48-50.

25. Sharma, S.K., Soodan, J.S. and Sharma, N. (2011) Haematobiochemical alterations in canine dermatitis. Indian Vet. J., 88(4): $56-58$.

26. Schalm, O.W. (1963) Interpretation of leukocyte response in the dog. J. Am. Vet. Med. Assoc.,142: 147-152.

27. Kumar, G.L. and Kiernan, J.A. (2010)Special stains in dermatopathology. Pathology Education Guide - Special Stains and $\mathrm{H}$ and E. $2^{\text {nd }}$ ed. Dako North America, California. p200.

\section{$* * * * * * * *$}

